\title{
Breakdown of Corn Fiber by a Metagenomic Ferulolyl Esterase in Combination with Glycosyl Hydrolases
}

\author{
Dominic W. S. Wong1*, Victor J. Chan', Hans Liao² \\ ${ }^{1}$ Western Regional Research Center, United States Department of Agriculture, Agricultural Research Service, Albany, USA \\ ${ }^{2}$ Cargill Biotechnology Development Center, Minneapolis, USA \\ Email: ${ }^{\star D}$ ominic.Wong@ars.usda.gov
}

How to cite this paper: Wong, D.W.S., Chan, V.J. and Liao, H. (2021) Breakdown of Corn Fiber by a Metagenomic Ferulolyl Esterase in Combination with Glycosyl Hydrolases. Advances in Enzyme Research, 9, 91-100.

https://doi.org/10.4236/aer.2021.94008

Received: October 25, 2021

Accepted: December 27, 2021

Published: December 30, 2021

Copyright $\odot 2021$ by author(s) and Scientific Research Publishing Inc. This work is licensed under the Creative Commons Attribution International License (CC BY 4.0).

http://creativecommons.org/licenses/by/4.0/

\begin{abstract}
A feruloyl esterase (FAE-C6) gene of 957 bp was isolated from rumen microbial metagenome, subcloned into pET32b vector, and expressed in Escherichia coli. The enzyme purified in active form, consisted of 319 amino acid residues, with a molecular weight of 43.7 based on SDS-PAGE. Homology modeling showed that the FAE contained the catalytic triad composed of $\operatorname{Ser}_{154} \mathrm{Asp}_{263} \mathrm{His}_{295}$ and a classical Gly-X-Ser ${ }_{154}$-X-Gly nucleophile motif commonly found in esterases. The FAE-C6 was characterized using corn fiber as substrate. Its combining action with glycoside hydrolases $(\mathrm{C}, \mathrm{X}, \mathrm{A})$ individually and in various combinations was studied with focus on the difference in the effects on FA and sugar release. Glycoside hydrolases with endo-xylanase included in the enzyme mixture showed significant impact on increasing the FA yield. For the release of sugar, FAE enhanced the yield in all hydrolase combinations moderately and endo-xylanase was not the key factor in the enzyme formulation.
\end{abstract}

\section{Keywords}

Feruloyl Esterase, Ferulic Acid Esterase, Ferulic Acid, Metagenomics, Corn Fiber

\section{Introduction}

Corn fiber (CF) is a mixture of coarse fiber from kernel pericarp or hull and fine fiber from endosperm $\mathrm{m}$ cellular materials in the corn kernel. The major components consist of hemicellulose (50\%), cellulose $(20 \%)$, starch $(11 \%-23 \%)$, protein (15\%), lignin (15\%) and ash, and $2 \%$ to $3 \%$ oil [1]. The structural complexity of $\mathrm{CF}$ is due to the large hemicellulose fraction, consists of heteroxylan, which in its native state, has $70 \%$ of the $\beta$-(1,4)-xylopyranosyl (Xylp) backbone 
carrying arabinofuranosyl, acetyl, glucuronyl side groups, and oligosaccharide chains containing galactose, xylose, and arabinose [2] [3]. Arabinofuranosyl side units are often ester-linked with ferulic acid moieties that can form crosslinks. In 2017 [4], $6.7 \times 10^{5}$ tons of corn was wet-milled, producing about $6.4 \times 10^{4}$ tons of corn fiber yearly. Corn fiber from wet-milling process is almost completely insoluble and highly recalcitrant with $50 \%$ of the starting material surviving pretreatment, enzymatic hydrolysis and fermentation (as used in corn ethanol production). Recent studies revealed that resistant complex xylan oligomers (remained non-degraded) contain ferulic acid, diferulates, acetic acid, galactose, arabinose, and uronic acid groups [5]. A common structural feature represents a sidechain of $\alpha$-L-galactopyranosyl-(1,2)- $\beta$-D-xylopyranosyl-(1,2)-5-O-trans-feruloyl-L-arabinof uranosyl group attached to the $O-3$ position of the $\beta$-1,4 linked xylosyl residue [6] [7]. The recalcitrance of CF can be ascribed to feruloylation of the side units and/or backbone of the xylan structure.

A variety of bacteria and fungi are known to produce feruloyl esterases (FAE, EC 3.1.1.73) that catalyze the cleavage of feruloyl-arabinose (Araf-FA) ester bonds linking ferulic acids to arabinofuranosyl side groups of the xylan main chain. It has been proposed that enzymes, such as FAE, can be used to augment the hydrolytic efficiency of cellulases and hemicellulases in biomass conversion, thus requiring less severe pretreatment conditions [8] [9]. Direct cloning of metagenomes provides high efficiency exploration of the sequence space of unculturable microbial communities for novel gene discovery and biocatalyst development. Most studies on the enzymology of feruloyl esterases focus on the reaction of hydrolyzing FA from the substrate. In a previous study, combinatorial enzyme approach has been applied for production and screening of libraries of feruloyl oligosaccharides [10]. The objective of this paper is to report the effect of cellulolytic and xylanolytic enzymes individually or in combination acting synergistically with FAE for the hydrolysis of CF with focus on sugar release.

\section{Experimental}

\section{Cloning of Feruloyl Esterase}

Metagenomic DNA was isolated from the microflora of a cow's rumen, and was used to construct a $\lambda$ ZAP library. Library screening for FAE enzyme activity identified the FAE-C6 gene. It was subcloned in pET vector, transformed in BL21, and the protein was purified to homogeneity, using previously reported procedures [11] [12].

\section{Bioinformatics}

Sequence analysis was performed using Vector NTI (Informax, Bethesda, MD, USA) and Geneious (Biomatters Ltd., Auckland, New Zealand). The gene sequence was submitted to GenBank with the accession number: MK607950.

\section{Electrophoresis}

The purified enzyme was run on a Bis-Tris NuPAGE gradient gel (4\% - 12\%) using $50 \mathrm{mM}$ 3-morpholinopropane-1-sulfonic acid (MOPS) buffer solution at constant $100 \mathrm{~V}$ for $2 \mathrm{~h}$. The developed gel was stained with SimplyBlue Safe stain 
(Invitrogen, Carlsbad, CA, USA). The protein and marker bands were analyzed by image analysis software (Alpha Inotech, AlphaImager, San Jose, CA, USA).

For $\mathrm{pI}$ determination, the enzyme protein was run on an electrofocusing gel $(\mathrm{pH}$ 3 to 10, Invitrogen, Carlsbad, CA, USA). Serva IEF markers 3 - 10 mix (Biophoretics, Reno, NV, USA, Heidelberg, Germany) was used as standards.

\section{Enzyme Activity Measurement}

A typical enzyme reaction mixture contained $100 \mathrm{mg} \mathrm{CF}$ and various nmole concentrations of FAE-C6 in $1 \mathrm{ml}$ volume of $50 \mathrm{mM} \mathrm{K}_{2} \mathrm{HPO}_{4}, \mathrm{pH} 7.0$ buffer, and was incubated for $2 \mathrm{~h}$ in a $40^{\circ} \mathrm{C}$ shaker bath. For all reactions, the $\mathrm{CF}$ was milled $3 \times 10$ s (Micro-Mill, Technilab Instruments, Vineland, NJ, USA), washed 4X with water, and oven-dried at $50^{\circ} \mathrm{C}$. Activity was expressed as $\mu \mathrm{g}$ FA released from $100 \mathrm{mg}$ substrate per hour measured by high performance liquid chromatography analysis. The HPLC system (Gilson 307 HPLC, Middleton, WI, USA) consisted of a Gilson 307 pump equipped with a Brownlee analytical C18 column $(260 \times 4.5 \mathrm{~mm})$, using a mobile phase of water/formic acid/acetonitrile $(7 / 1 / 2 \mathrm{v} / \mathrm{v})$ at a flow rate of $0.2 \mathrm{~mL} / \mathrm{min}$ at ambient temperature. Ferulic acid peaks were detected at $315 \mathrm{~nm}$.

\section{Enzyme pH and Temperature Optima and Stability}

For $\mathrm{pH}$ optimum, the reaction mixture of $100 \mathrm{mg} \mathrm{CF}$ and $0.3 \mathrm{nmole}$ FAE-C6 in $0.5 \mathrm{~mL}$ universal buffer of varying $\mathrm{pH}$ was incubated for $2 \mathrm{~h}$ in a $37^{\circ} \mathrm{C}$ shaker bath. For determining $\mathrm{pH}$ stability, the $\mathrm{C} 6$ was incubated at various $\mathrm{pH}$ at $37^{\circ} \mathrm{C}$ for $4 \mathrm{hr}$, reconstituted to $\mathrm{pH} 6.0$, and the residual activity was determined by adding the CF substrate. For temperature optimum, the enzyme reaction mixture was incubated in $100 \mathrm{mM} \mathrm{K}_{2} \mathrm{HPO}_{4}$ buffer, at $\mathrm{pH} 7.0$ at temperatures from $20^{\circ} \mathrm{C}$ to $70^{\circ} \mathrm{C}$ for $2 \mathrm{~h}$.

\section{Alkali Hydrolysis of Corn Fiber}

A sample of $200 \mathrm{mg} \mathrm{CF}$ in $6 \mathrm{~mL} 1 \mathrm{~N} \mathrm{NaOH}$ was incubated for $16 \mathrm{~h}$ in a $37^{\circ} \mathrm{C}$ shaker bath [13]. Following centrifugation, the supernatant was recovered and adjusted to a $\mathrm{pH} \leq 2$ with $\mathrm{HCl}$. Ferulic acid products were then extracted with ethyl acetate $(3 \times 3 \mathrm{~mL})$, dried under $\mathrm{N}_{2}$, and dissolved in $\mathrm{CH}_{3} \mathrm{OH}: \mathrm{H}_{2} \mathrm{O}(1: 1 \mathrm{v} / \mathrm{v})$ for HPLC analysis.

\section{Activity with Added Accessory Enzymes}

To $100 \mathrm{mg}$ of CF, 0.5 nmole FAE-C6 was added, supplemented with endoxylanase (XYN, endo-1,4- $\beta$-xylanase, GH11), $\alpha$-L-arabinofuranosidase (ABF), and cellulase (CEL, endo-1,4- $\beta$-D-glucanase) all from Aspergillus niger (Megazyme, Bray, Ireland) in various nmole concentrations. The three enzymes were added individually and in various combinations to the C6 reaction. The mixture was incubated for $2 \mathrm{~h}$ in a $40^{\circ} \mathrm{C}$ shaker bath. These enzymes exhibit optimum $\mathrm{pH}$ of 4.5 and temperature at $40^{\circ} \mathrm{C}$.

\section{Results and Discussion}

\section{Isolation, Cloning, and Bioinformatics of the FAE Gene}

The genomic insert isolated from metagenomic library contained an esterase 
$\begin{array}{lllll}1 & 10 & 20 & 30 & 40\end{array}$

Fae C6 MKKTLLTVMLCMAAVVMAOPGGGFGGFGGFORPOVKLEफSOERKDV

Prevotella sp. MKKTLLSTVMLCMASLVMAOPGGGFGGFGGFQRPOVKLETSOEKKDV

Bacteroidaceae... 鱼-------
50
60
70
80
90

Fae C6

Prevotella sp.

NYAGDDQAYHTCDIYLPKEEKASYPVVIHIYGSAKFSNNGRGA'ADLG

Bacteroidaceae...

ADDOAYHTCD IY IPKEERSSYPVV IHIYGSAKFSNSGRS OADLG DYAGDDKAYHTCDIYLPKKEQASYPVVIHIYGSAKFSNNS BGAADLG

100

110

120

130

140

Fae C6

TIVNALIKAGYAVVCPNHRSSGDAKWPAOIHDIRAVIRFVRGEAKKY

Prevotella sp. TIVNALLKAGYAVVCPNHR SSMDAKKPAOIHDIRAVIRFVRGEAKRY

Bacteroidaceae... TIVKSLLDAGFAVVCPNHR SSMDAKKPAOIHDIRAVIRFVRGEAKKY

$150 \stackrel{h}{h} \quad 160 \quad 170 \quad 180$

Fae C6 KFDPSFVATSGFSSGGHLA STAATSGLKOTKVGTYDIDLEGTLGCY

Prevotella sp. KFDP SFVATSGFSSGGHLASTAATTSEL KOTKVGTYDIDLEGTIGCY

Bacteroidaceae... KFDT KFIATSGFSSGGHLASTAATTSGT KOTKVGTVDIDLEGNVGNV

$190 \quad 200 \quad 210 \quad 220 \quad 230$

Fae C6 ANESSSVNAACDKSGPVDLMAMDCGEGMKMGENSPEDVLLDSKIAKE

Prevotella sp. ANESSSVNAACDKSGPVDLTAMDCGEGMKMGENSPEDMLLNSKID KE

Bacteroidaceae... L IESSAVNAACDK SGP I DLFAMDCGES MKMGENSPEDVLLNSKLAKE

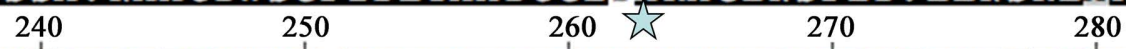

Fae C6

PDKYRSLSAT YYVNKKNPPIIIFHGEKDNVVPCCQGKMFYEKIVAAG

Prevotella sp. PDKYRSLSATYYVNKNNPPIIIFHGEKDNVVPCCOGKMFYGKIVAG

Bacteroidaceae...

Fae C6 PDKYLSLSAN TYVDKNDPPVI IFHGEKDNVVPCCOGKA FYET IRAAG 290

$\hat{W}$

300

310

320

VKTEATFVPEGGEG-M GMYDEANLOKMVNFLNAVR T GK

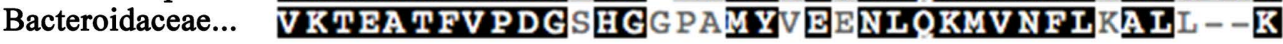

Figure 1. Multiple sequence alignment of FAE-C6. Prevotella sp. and Bacteroidaceae bacterium $\alpha / \beta$ fold hydrolases isolated from ruminant gastrointestinal micobiome MBP5715121 and MBQ9883982 show identity percentages of $96.6 \%$ and $75.8 \%$, respectively. The Gly-X-Ser ${ }_{154}$-X-Gly motif sequence is highlighted with a striated bar above the residues. The catalytic triad $\mathrm{Ser}_{154} \mathrm{Asp}_{263} \mathrm{His}_{295}$ is indicated with stars above the residues. 


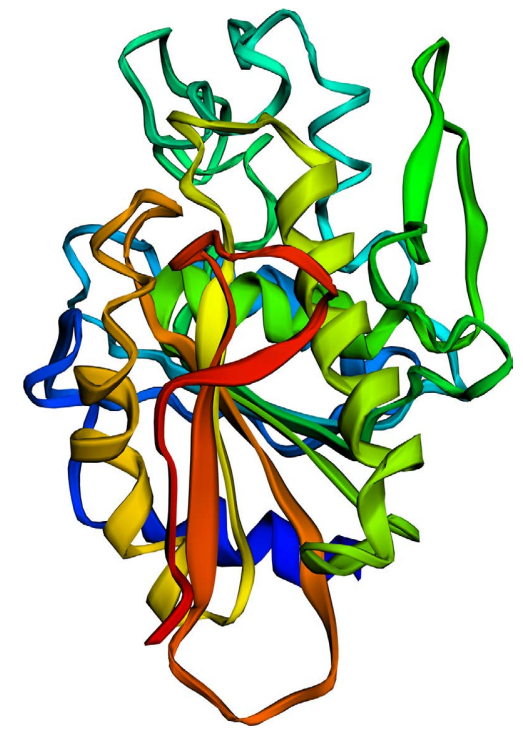

Figure 2. The 3D model of FAE-C6. Homology modeling based on comparison with the high conserved C-terminal region of the Bacteroides eggershii bifunctional protein BeGH43/FAE (PDB 6MLY) [14] as template. All images and data generated by Phyre2 $[22]$.

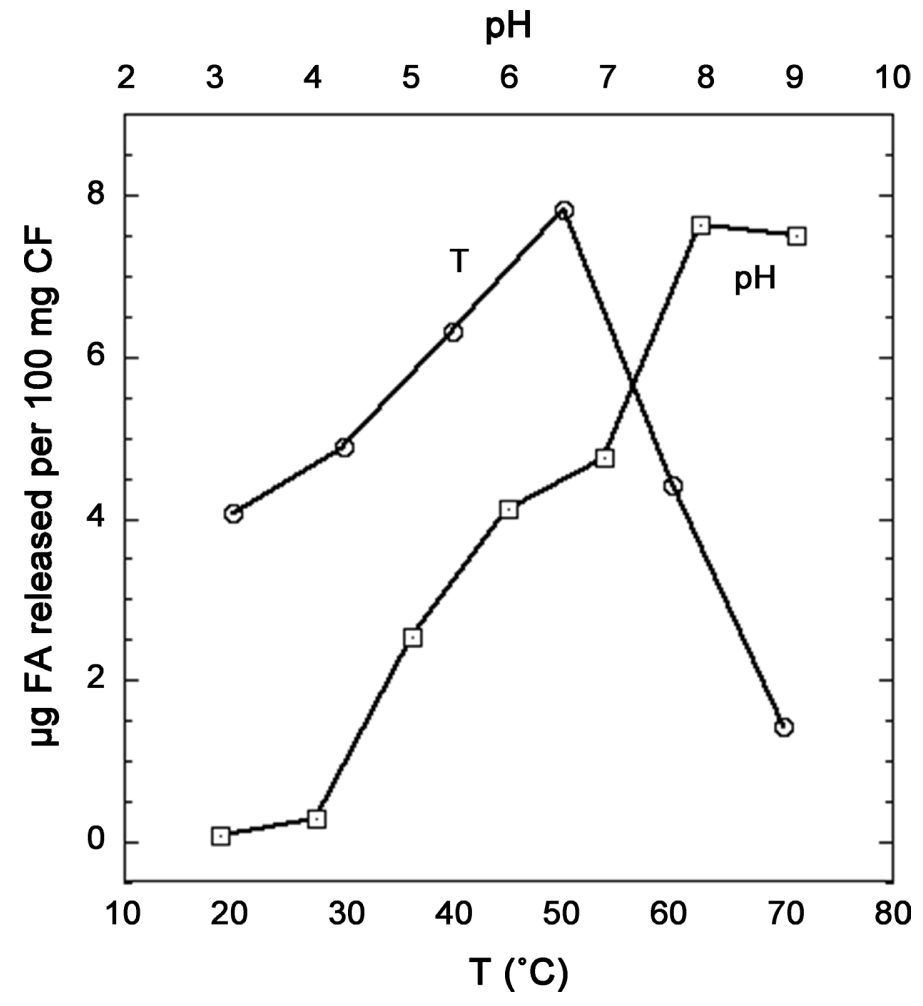

Figure 3. Effects of $\mathrm{pH}$ and temperature on FAE-catalyzed release of ferulic acid from CF. Reaction conditions: $100 \mathrm{mg} \mathrm{CF}, 1 \mathrm{ml}$ universal buffer of varying $\mathrm{pH}, 1 \mathrm{nmole}$ FAE-C6, varying temperature, incubated for $2 \mathrm{hr}$.

for $2 \mathrm{~h}$ at $50^{\circ} \mathrm{C}$ ), $1 \mathrm{nmole}$ FAE catalyzed the release of $7.8 \mu \mathrm{g}$ FA from $100 \mathrm{mg}$ $\mathrm{CF} / \mathrm{h}$ equivalent to $1.3 \%$ of total FA content in the $100 \mathrm{mg} \mathrm{CF}$ (as determined by alkaline hydrolysis) used in the reaction mixture. 


\section{Glycoside Hydrolases Activities on Sugar Release from CF}

The following three glycoside hydrolases were tested individually or in various combinations in catalyzing sugar release from CF: endo-1,4- $\beta$-D-glucanase (endo-cellulase, EC 3.2.1.4, GH12), endo-1,4- $\beta$-xylanase (EC 3.2.1.8, GH11), $\alpha$-Larabinofuranosidase (EC 3.2.1.55, GH51), labeled as $\mathrm{C}, \mathrm{X}$ and $\mathrm{A}$ in the figures, respectively. All enzymes are from Aspergillus niger, and exhibit $\mathrm{pH}$ and temperature optima of $4.0-4.5$ and $60^{\circ} \mathrm{C}$, respectively (specifications from Megazyme, Ireland). The enzymes ( $2 \mathrm{U}$ each) were added individually and in combinations to $100 \mathrm{mg} \mathrm{CF}$ in $\mathrm{pH} 5.0$ buffer, incubated for $2 \mathrm{hr}$ at $37^{\circ} \mathrm{C}$. Figure 4 shows that combinations of the enzymes substantially increased the sugar yield compared to single enzymes. A combination of CXA increased the sugar yield by 93\% over that by cellulase alone. Likewise, combination of XA increased the yield by $167 \%$ and $245 \%$, respectively, over that by X or A alone.

\section{Effect of FAE added to Glycoside Hydrolases}

FAE alone had little effect on the sugar yield (Figure 5). It is evident that the sugar yield was largely attributed to the actions of glycoside hydrolases. Adding FAE-C6 to CXA increased the yield by $6.5 \%$ and $17.6 \%$, respectively at $\mathrm{pH} 5$ and 6. Apparently, it was the non-covalent sugar molecules in the fiber complex that was released by the action of FAE. The sugar released in this case may not represent entirely hydrolytic products. The sugar yield decreased with increasing $\mathrm{pH}$, with a $40 \%$ reduction when the reaction was performed at $\mathrm{pH} 7$ instead of pH 5 (Figure 5). This result suggests further evidence that the hydrolase enzymes (CXA) provided key catalytic actions in the release of sugar from the CF substrates.

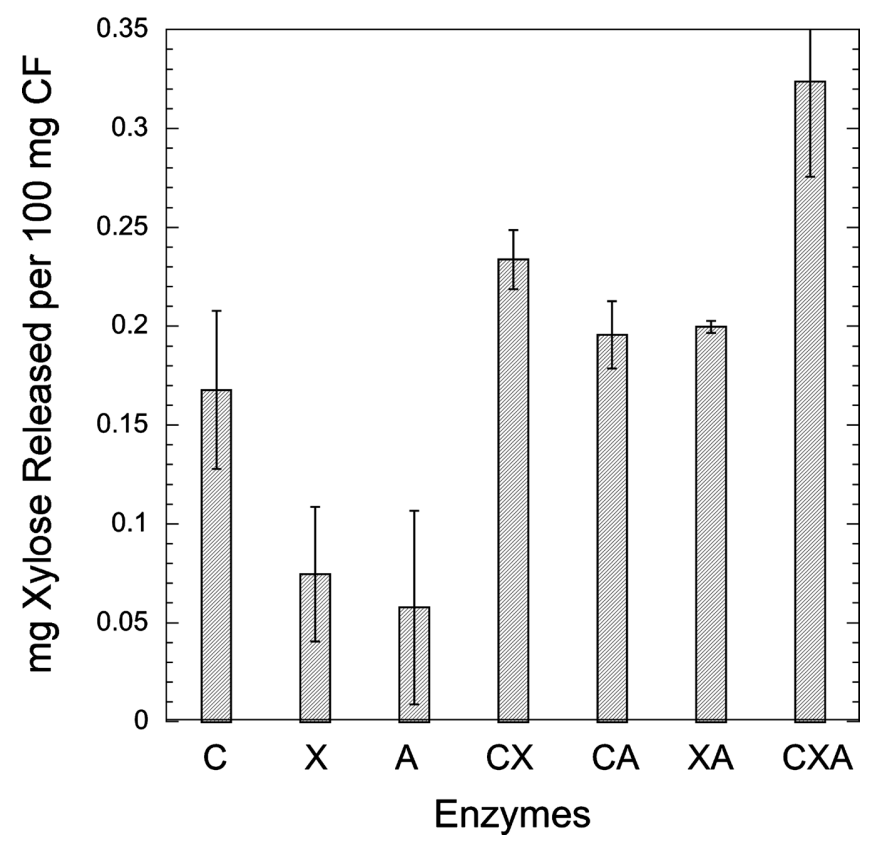

Figure 4. Effects of cellulase, xylanase, and arabinofurnosidase acting individually (C, X, $\mathrm{A}$ ) or in combinations (CX, CA, XA, CXA) in the release of sugar (as xylose equivalent) from CF. Reaction conditions: $100 \mathrm{mg} \mathrm{CF}, 2 \mathrm{U}$ each enzyme, $\mathrm{pH} 5.0,37^{\circ} \mathrm{C}$ for $2 \mathrm{hr}$. 


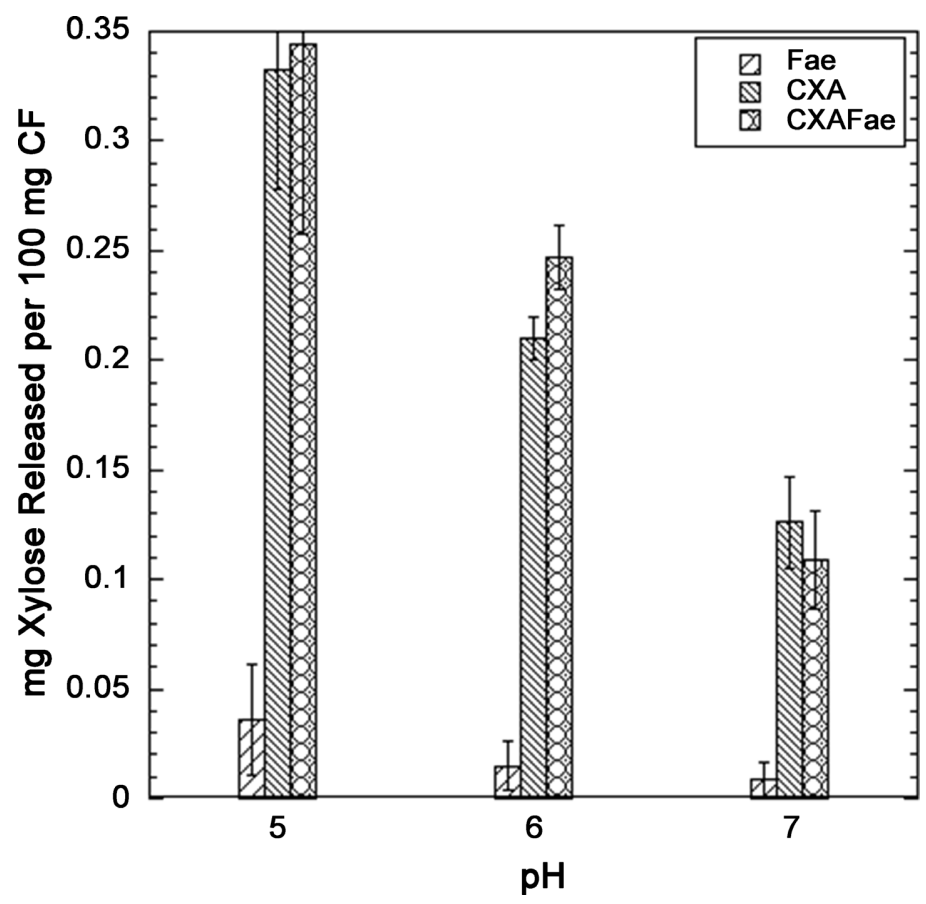

Figure 5. Effects of adding $\mathrm{FAE}$ to $\mathrm{C}+\mathrm{X}+\mathrm{A}$ enzymes combination in various $\mathrm{pH}$ coniditions: $100 \mathrm{mg} \mathrm{CF}, 0.3$ nmole FAE-C6, $2 \mathrm{U}$ each of $\mathrm{C}+\mathrm{X}+\mathrm{A}$ combined, buffer at $\mathrm{pH}$ 5.0, 6.0 or $7.0,37^{\circ} \mathrm{C}, 2 \mathrm{hr}$.

\section{Effect of FAE-C6 on FA and Sugar Release}

Adding FAE-C6 to the glycoside hydrolases ( $\mathrm{C}, \mathrm{X}, \mathrm{A})$ individually and in combinations affects the release of FA and Sugar in different patterns. The release of FA was enhanced in CXF, XAF and CXAF, showed similar increases of, $6.9 \%, 8.7 \%$ and $8.3 \%$, respectively compared to FAE alone (Figure 6(a)). All these three enzyme mixtures contained endo-xylanase. It is noted that the treatment with CAF (which contain no endo-xylanese) showed a $21.7 \%$ decrease in the FA yield. The synergistic action of endo-xylanase has been extensively investigated in our previous studies. Adding increasing concentrations of endo-xylanase $(1.0$ nmole to 20 nmole) at a constant concentration $(0.5 \mathrm{nmole})$ of FAE resulted in an average increase of $1.11 \pm 0.14 \mu \mathrm{g}$ of FA for each doubling of the concentration of the xylanase [10]. The release of FA from CF and corn bran by FAE in synergism has been reported to be in a similar range, 1.21 and 1.19 fold, respectively [17]. The enhancement by endo-xylanase is due to the formation of shorter chain xylooligosacchatides, which are more susceptible (hydrolyzed at faster rates by FAE) than long chain substrates [18] [19]. Furthermore, FAE are known to act synergistically with endo-xylanases in the release if FA, because short-chain feruloylated xylo-oligosaccharides are better substrates with a higher rate of Araf-FA cleavage [17]. Other xylanolytic accessory enzymes that act on various side chains may also enhance the hydrolysis of xylan main chain and in turn the ferulic acid linkage [20] [21]. However, our previous studies showed that arabinofuranosidase and acetylxylan esterase showed no synergistic effect on the CF substrate under similar experimental conditions [10]. 
(a)

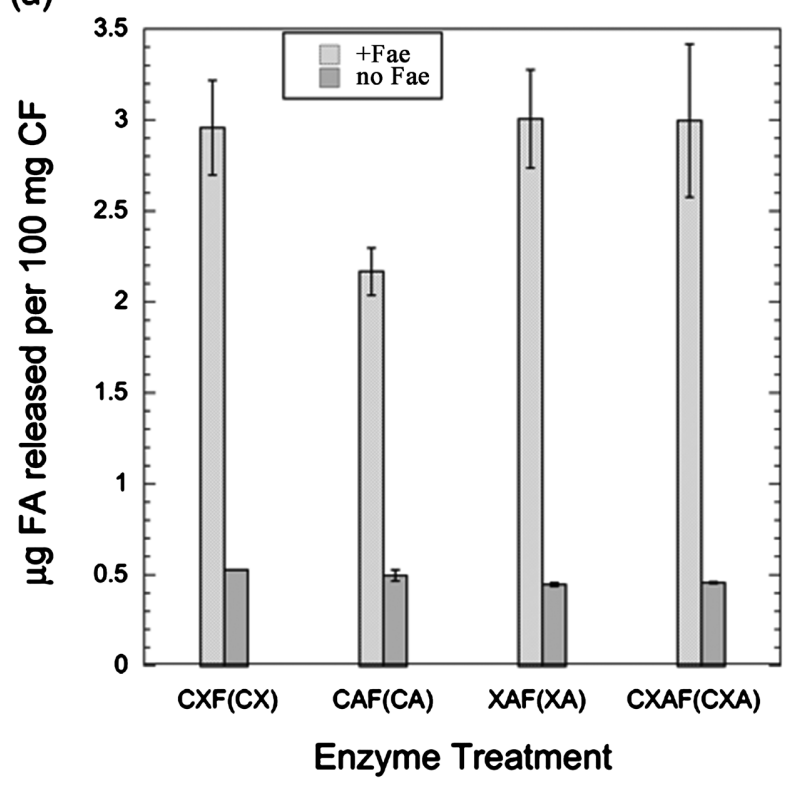

(b)

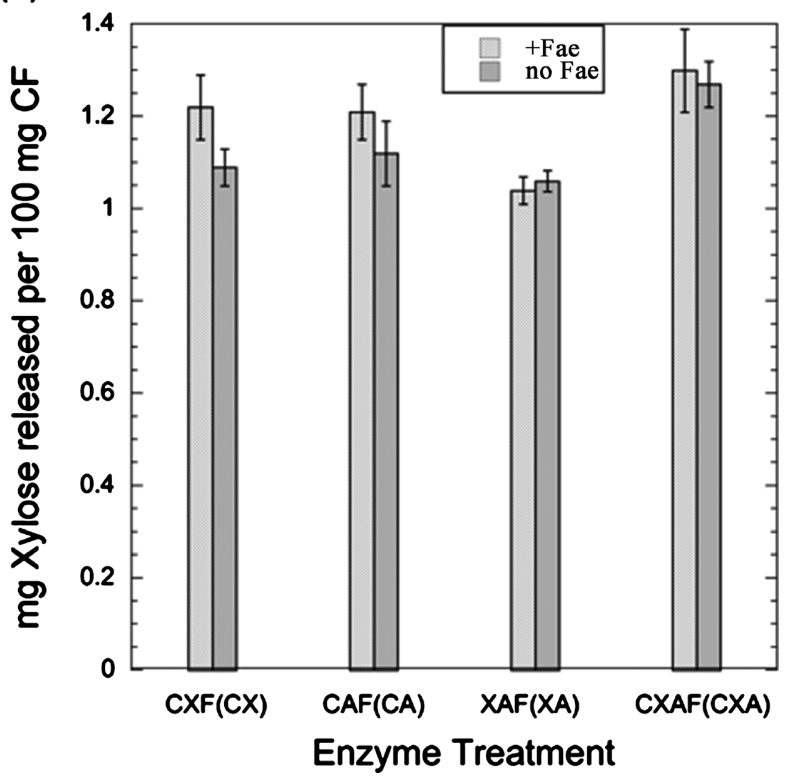

Figure 6. Effect of adding FAE to various combinations of glycoside hyudrolases (CX, CA, XA, CXA) on the release of (a) FA, (b) sugar as xylose equivalent from CF substrate. Reaction conditions: $100 \mathrm{mg} \mathrm{CF}, 0.3 \mathrm{nmole} F A E, 2 \mathrm{U}$ each of the hydrolases, $\mathrm{pH} 5.0,37^{\circ} \mathrm{C}, 2 \mathrm{hr}$.

The effect of adding FAE-C6 to the glycoside hydrolases mixtures showed a different product patterns on sugar release (Figure 6(b)). The increase in sugar release was very moderate in all cases (CXF, CAF, XAF, CXAF), showing 8.0\% and $11.9 \%$ increase in the CXF and CXAF enzyme mixtures, respectively. The results indicate that the influence of endo-xylanase was no different from the other enzymes, (2) addition of FAE enhanced the sugar yield in all enzyme combinations, but was not a key factor for sugar release in the reactions.

\section{Conclusion}

A feruloyl esterase (FAE) gene was isolated from rumen microbial metagenome, expressed in E. coli, and the enzyme protein (fae-C6) was purified in active form. It consists of an esterase domain with an $\alpha / \beta$ hydrolase fold, composed of a catalytic triad $\mathrm{Ser}_{154} \mathrm{Asp}_{263} \mathrm{His}_{295}$. The FAE-C6 was characterized using corn fiber as substrate. Its combining action with glycoside hydrolases $(\mathrm{C}, \mathrm{X}, \mathrm{A})$ individually and in various combinations was studied with focus on the difference in the hydrolytic effects on FA and sugar release. Glycoside hydrolases with endoxylanase included in the enzyme mixture show significant impact on increasing the FA yield. For the release of sugar, FAE enhanced the xylose yield in all hydrolases moderately with $11.9 \%$ the highest increase in CXAF. Endo-xylanase was not the key factor in the enzyme formulation.

\section{Acknowledgements}

Reference to a company and/or product is only for purposes of information and does not imply approval of recommendation of the product to the exclusion of 
others that may also be suitable. All programs and services of the U.S. Department of Agriculture are offered on a nondiscriminatory basis without regard to race, color, national origin, religion, sex, age, marital status, or handicap. The authors declare that there is no conflict of interest regarding the publication of this paper.

\section{Conflicts of Interest}

The authors declare no conflicts of interest regarding the publication of this paper.

\section{References}

[1] Hames, B.R. (2009) Biomass Compositional Analysis for Energy Application. In: Mielenz, J.R., Ed., Biofuels, Humana Press, Totowa, 147-167. https://doi.org/10.1007/978-1-60761-214-8_11

[2] Biely, P., Vrsanska, M., Tenkanen, M. and Kluepfel, D. (1997) Endo- $\beta$-1,4-Xylanase Families: Differences in Catalytic Properties. Journal of Biotechnology, 57, 151-166. https://doi.org/10.1016/S0168-1656(97)00096-5

[3] Biely, P., Singh, S. and Puchart, V. (2016) Towards Enzymatic Breakdown of Complex Plant Xylan Structures: State of the Art. Biotechnology Advances, 34, 1260-1274. https://doi.org/10.1016/j.biotechadv.2016.09.001

[4] National Agricultural Statistics Service (NASS) (2018) Grain Crushings and Co-Products Production (USDA NASS Report). NASS, Washington DC.

[5] Appeldoorn, M.M., Kabel, M.A. and van Eylen, D. (2010) Characterization of Oligomeric Xylan Structures from Corn Fiber Resistant to Pretreatment and Simultaneous Saccharification and Fermentation. Journal of Agricultural and Food Chemistry, 58, 11294-11301. https://doi.org/10.1021/jf102849x

[6] Agger, J., Vikso-Nielsen, A. and Meyer, A.S. (2010) Enzymatic Xylose Release from Pretreated Corn Bran Arabinoxylan: Differential Effects of Deacetylation and Deferuloylation on Insoluble and Soluble Substrate Fractions. Journal of Agricultural and Food Chemistry, 58, 6141-6148. https://doi.org/10.1021/jf100633f

[7] Appeldoorn, M.M., de Waard, P., Kabel, M.A., Cruppen, H. and Schols, H.A. (2013) Enzyme Resistant Feruloylated Xylooligomer Analogues from Thermochemically Treated Corn Fiber Contain Large Side Chains, Ethyl Glycosides and Novel Sites of Acetylation. Carbohydrate Research, 381, 33-42. https://doi.org/10.1016/j.carres.2013.08.024

[8] Akin, D.E. (2007) Grass Lignocelluloses. Applied Biochemistry and Biotechnology, 137, 3-15. https://doi.org/10.1007/s12010-007-9035-5

[9] Wong, D.W.S., Chan, V.J. and Liao, H. (2021) Hydrolysis of Ferulic Acids in Corn Fiber by a Metagenomic Feruloyl Esterase. Bioresources, 16, 825-834. https://doi.org/10.15376/biores.16.1.825-834

[10] Wong, D.W.S., Chan, V.J. and Liao, H. (2020) Combinatorial Enzyme Approach for Production and Screening of Libraries of Feruloyl Oligosaccharides. Advances in Enzyme Research, 8, 27-37. https://doi.org/10.4236/aer.2020.83003

[11] Wong, D.W.S., Takeoka, G., Chan, V.J., Liao, H. and Murakami, M.T. (2015) Cloning of a Novel Feruloyl Esterase from Rumen Microbial Metagenome for Substantial Yield of Mono- and Diferuic Acids from Natural Substrates. Protein \& Peptide Letters, 22, 681-688. https://doi.org/10.2174/0929866522666150428114053 
[12] Shang, M.L., Chan, V.J., Wong, D.W.S. and Liao, H. (2018) A Novel Method for Rapid and Sensitive Metagenomic Activity Screening. MethodsX, 5, 669-675. https://doi.org/10.1016/j.mex.2018.06.011

[13] Bartolome, B., Fauld, C.B., Kroon, P.A., Waldron, K., Gilbert, H.J., Hazlewood, G. and Williamson, G. (1997) An Aspergillus niger Esterase (Ferulic acid Esterase III) and a Recombinant Pseudomonas fluorescens subsp. Cellulosa Esterase (XylD) Release a 5-5' Ferulic Dehydrodimer (Diferulic Acid) from Barley and Wheat Cell Walls. Applied and Environmental Microbiology, 63, 208-212.

[14] Pereira, G.V., Abdel-Hamid, A.M., Dutta, S.D., Alessandro-Gabazza, C.N., Welers, D., Farris, J.A., Bajaj, S., Wawrzak, Z., Atomi, H., Mackie, R.I., Gabazza, E.C., Shukla, D. and Koropatkin, N.M. (2021) Degradation of Complex Arabinoxylan by Human Colonic Bacteriodetes. Nature Communications, 12, Article No. 459 https://doi.org/10.1038/s41467-020-20737-5

[15] Brenner, S. (1988) The Molecular Evolution of Genes and Proteins: A Tale of Two Serines. Nature, 334, 528-530. https://doi.org/10.1038/334528a0

[16] Ollis, D.L., Cheah, E., Cygler, M., Dijkstra, B., Frwlow, F., Franken, S.M., Harel, M., Remington, S.J., Silman, I., Schrag, J., Sussman, J.L., Verschueren, K.H.G. and Goldman, A. (1992) The $\alpha / \beta$ Hydrolase Fold. Protein Engineering, Design and Selection, 5, 197-211. https://doi.org/10.1093/protein/5.3.197

[17] Wong, D.W.S., Chan, V.J., Liao, H. and Zidwick, M.J. (2013) Cloning of a Novel Feruloyl Esterase Gene from Rumen Microbial Metagenome and Enzyme Characterization in Synergism with Endoxylanases. Journal of Industrial Microbiology and Biotechnology, 40, 287-295. https://doi.org/10.1007/s10295-013-1234-1

[18] Faulds, C.B. and Williamson, G. (1993) Ferulic Acid Esterase from Aspergillus niger. Purification and Partial Characterization of Two Forms from a Commercial Source of Pectinase. Biotechnology and Applied Biochemistry, 17, 249-259.

[19] Faulds, C.B. and Williamson, G. (1995) Release of Ferulic Acid from Wheat Bran by a Ferulic Acid Esterase (FAE-III) from Aspergillus niger. Applied Microbiology and Biotechnology, 43, 1082-1087. https://doi.org/10.1007/BF00166929

[20] Vardakou, M., Katapodis, P., Topakas, E., Kekos, D., Macris, B.J. and Christakopoulos, P. (2004) Synergy between Enzymes Involved in the Degradation of Insoluble Wheat Flour Arabinoxylan. Innovative Food Science \& Emerging Technologies, 5, 107-112. https://doi.org/10.1016/S1466-8564(03)00044-4

[21] Wong, D.W.S. (2006) Feruloyl Esterase-A Key Enzyme in Biomass Degradation. Applied Biochemistry and Biotechnology, 133, 87-112. https://doi.org/10.1385/ABAB:133:2:87

[22] Kelly, L.A., et al. (2015) The Phyre2 Web Portal for Protein Modeling, Prediction and Analysis. Nature Protocols, 10, 845-858. https://doi.org/10.1038/nprot.2015.053 